\title{
Owner-managers' transformational leadership behaviours and human resource strategies: A case of small fast-food restaurants in South Africa
}

\begin{tabular}{|c|c|}
\hline \multicolumn{2}{|c|}{$\begin{array}{l}\text { Authors: } \\
\text { Lebohang Ntlhanngoe }^{1} \\
\text { Crispen Chipunza }^{1}\end{array}$} \\
\hline \multicolumn{2}{|c|}{$\begin{array}{l}\text { Affiliations: } \\
{ }^{1} \text { Department of Business } \\
\text { Management, Faculty of } \\
\text { Management Sciences, } \\
\text { Central University of } \\
\text { Technology, Bloemfontein, } \\
\text { South Africa }\end{array}$} \\
\hline \multicolumn{2}{|c|}{$\begin{array}{l}\text { Corresponding author: } \\
\text { Crispen Chipunza, } \\
\text { cchipunza@cut.ac.za }\end{array}$} \\
\hline \multicolumn{2}{|c|}{$\begin{array}{l}\text { Dates: } \\
\text { Received: } 15 \text { Sept. } 2020 \\
\text { Accepted: } 20 \text { Nov. } 2020 \\
\text { Published: } 28 \text { June } 2021\end{array}$} \\
\hline \multicolumn{2}{|c|}{$\begin{array}{l}\text { How to cite this article: } \\
\text { Ntlhanngoe, L., \& Chipunza, } \\
\text { C. (2021). Owner-managers' } \\
\text { transformational leadership } \\
\text { behaviours and human } \\
\text { resource strategies: A case of } \\
\text { small fast-food restaurants in } \\
\text { South Africa. SA Journal } \\
\text { of Human Resource } \\
\text { Management/SA Tydskrif vir } \\
\text { Menslikehulpbronbestuur, } \\
\text { 19(0), a1482. https://doi. } \\
\text { org/10.4102/sajhrm. } \\
\text { v19i0.1482 }\end{array}$} \\
\hline \multicolumn{2}{|c|}{$\begin{array}{l}\text { Copyright: } \\
\text { (c) 2021. The Authors. } \\
\text { Licensee: AOSIS. This } \\
\text { is licensed under the } \\
\text { Creative Commons } \\
\text { Attribution License. }\end{array}$} \\
\hline \multicolumn{2}{|l|}{ Read online: } \\
\hline 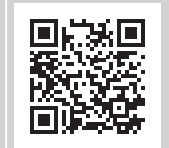 & $\begin{array}{l}\text { Scan this QR } \\
\text { code with your } \\
\text { smart phone or } \\
\text { mobile device } \\
\text { to read online. }\end{array}$ \\
\hline
\end{tabular}

Orientation: The proliferation of fast-food restaurants in South Africa calls for transformational leadership (TL) to keep the businesses afloat, through the application of competitive strategic human resource (HR) practices. However, there is shortage of evidence on how TL behaviours of owner-managers in this sector are related to their choice of HR strategies.

Research purpose: The purpose of the study was, therefore, to determine the relationship between owner-managers' TL behaviours and HR strategies relevant to small fast-food restaurants in a district in the Free State Province, South Africa.

Motivation of the study: Known studies emphasise that HR strategies can be linked to specific TL behaviours for business growth and survival. Nonetheless, no known study has been conducted within the South African context to establish the link between TL and HR strategies, particularly amongst the small fast food restaurants.

Design and method: A positivist research paradigm approach to test the relationships between the study variables. Quantitative data were collected through was used a self-administered questionnaire from $(n=102)$ small fast-food restaurants' owner-managers following a crosssectional study design. Descriptive and logistics regression data analyses techniques were used to make meaning out of data.

Main findings: The majority dimensions of TL behaviours and HR strategies are related and few not related.

Practical/managerial implications: The study offers insights into small fast-food restaurants' owner-managers' need to adapt leadership qualities depending on the HR strategy applied.

Contribution/value-add: The study adds to the body of knowledge on how TL precepts are applied in different strategic HR management contexts.

Keywords: owner-manager; transformational leadership; fast-food restaurant; human resource strategy; South Africa.

\section{Introduction}

In South Africa, fast-food restaurants are an ever-growing industry and its presence is visible in various parts of the country. This study is limited to local-owned fast-food restaurants categorised as small, macro and medium enterprises (SMMEs). Thus, international franchises were excluded from this study. Small fast-food restaurants that are smaller in size, with little or no seating capacity fast-food outlets where a range of ready-to-eat meals are provided (Mhlanga, 2018) are referred to in this study. Despite this contribution, the South Africa Hotel Restaurant Institutional Sector Report (2016) highlighted that a huge proportion of the country's small fast-food restaurants have been plagued by failure since 2014. Some of the reasons behind this failure are increased competition from supermarkets, retail chains, convenience stores, food caterers and informal traders (Insight Survey, 2016). In addition, finding talented, competent and skilled workforce, retaining them and turnover remain a challenge amongst these small businesses (Zwane et al., 2014, cited in Mupani \& Chipunza, 2019). These challenges adversely affect the small restaurants' bottom line (Nzonzo \& Matashu, 2014).

This study assumes that leadership and management of human resources (HRs) are some of the critical challenges that small fast-food restaurants are facing in South Africa. It is against this backdrop that this study investigates the relationship between the facets of transformational 
leadership (TL), which are (1) idealised influence, (2) inspirational motivation, (3) individualised consideration and (4) intellectual stimulation (Bass \& Riggio, 2006) and HR strategies (1) high-performance management (HPM), (2) high-commitment management (HCM) and (3) highinvolvement management (HIM) strategy called (HPM, HCM or HIM strategy as proposed by Armstrong \& Taylor, 2014). The justification for investigating the leadership construct is given impetus by literature, which shows that leadership behaviours, especially TL in small businesses, play a huge role in the creation of an organisation's competitive advantage and sustainability (McKinnonRussell, 2015). Studies also show that HR strategic practices in HPM strategy are commonly used amongst SMMEs. Evidently, practices attached to this strategy enhance employee performance and facilitate their engagement, motivation and skill development (Armstrong \& Taylor, 2014). With evidence that TL and HR strategies are necessary, it is possible to argue that strong focus on how the behaviour of a leader influences HR actions might assist in dealing with some of the people-related challenges bedeviling the small fast-food restaurant sector in South Africa.

\section{Research purpose and objectives}

The aim of this research study is to determine the relationship between TL behaviours and HR strategies within small fastfood restaurants in a district in the Free State Province of South Africa. The study is conducted against a background that, until recently, leadership and management of HR are some of the critical challenges faced by small fast-food restaurants in South Africa, yet they are seldom subjects of empirical investigation (Nyandiko \& Ongeri, 2015).

Given the above, the objective of the study is to determine the extent to which owner-managers' TL behaviours and HR strategies are correlated. Specifically, the study sought to answer the question 'To what extent are owner-managers' TL behaviours and HR strategies correlated within small fast-food restaurants?'

\section{Literature review}

\section{Transformational leadership}

According to Korejan and Shahbazi (2016), TL refers to leaders who seek to create ideas and new perspectives to create a new path of growth and prosperity in front of the organisation. Unlike, transactional leadership, a transformational leader is a person who stimulates and inspires followers to achieve extraordinary outcomes (Odumeru \& Ifeanyi, 2013). Transformational leadership has four constructs, namely idealised influence, inspirational motivation, individualised consideration and intellectual stimulation as stated here and each of these attributes are individually discussed in the following sections.

\section{Idealised influence}

Idealised Influence is described by Hamidianpour, Esmaeilpour and Mashayekh (2016) as a dimension of a TL where followers demonstrate respect and loyalty towards a leader who conveys an ideal sense and makes followers consider the leader as a perfect sense model of behaviour. This component makes the transformational leaders be admired and respected (Hamidianpour et al., 2016). In relation to respect, Gumusluoglu and Ilsev (2009) have suggested that TL through idealised influence can activate the trust and respect of their subordinates, thereby giving integrity to product innovation performance. This extends Alahmad (2016)'s conclusion that idealised influence plays a vital role in helping employees reach and exceed performance expectations, assisting them in both personal and organisational changes. In the context of this study, one can argue that, when restaurant followers and employees notice the leader displaying idealised influence behaviours, they are likely to attribute certain positive characteristics to him or her, which might result in increased performance.

\section{Inspirational motivation}

Inspirational motivation is defined by Steinmann, Klug and Maier (2018) as the method in which a transformational leader inspirationally motivates followers to achieve more than expected by sharing his or her vision in order to inspire them towards a more effective and efficient performance of their duties. From the performance point of view, Ngaithe, George, Lewa and Ndwiga (2016) concurred that inspirational motivation is positively and significantly related with staff performance. Researchers further emphasise that motivation not only increases the level of performances of employees but also increases their commitment in the workplace (Ukandu \& Ukpere, 2011). Therefore, considering the volatile environment that the restaurant industry is operating in, inspirational motivation is still important because workers experiencing a sense of purpose could express higher levels of commitment to the company and maybe less likely to contemplate leaving (Smith, 2018).

\section{Intellectual stimulation}

Intellectual stimulation refers to the leader's ability to instill innovative and creative capabilities into followers as a way of building their critical thinking and problem-solving skills (Atiku \& Anane-simon, 2020). Researchers claim that innovation and creativity are the decisive factors in any economic activity and thus, restaurant managers who encourage employees to be creative might be able to solve customer problems carefully (Elgelal \& Noermijati, 2015). For example, within the hospitality sector in Taiwan, Chou, Horng, Liu, Huang and Chung (2016) found that innovation and creativity play an important role in helping chefs to quickly prepare meals and serve customers on time.

\section{Individualised consideration}

Individualised consideration is a dimension of TL whereby a leader pays special attention to individual differences, followers' personal growth and needs for achievement by acting as a mentor or coach for them (Gonfa, 2019). In other words, transformational leaders may serve as mentors and coaches, and take into account individual needs and desires. 
This is arguably supported by Hautamaki (2016) that leaders who are effective in individual consideration behaviour are better seen to be friendly, supportive and encouraging towards self-development, which has a positive and significant effect on employee performance. Logically this corresponds to Ogola, Sikalieh and Linge (2017)'s view that when employees are provided with the opportunities where they are encouraged to grow and progress intellectually, their performance is likely to improve. Besides performance improvement, the Society for HR Management (2016) asserted that growing and progressing intellectually can also lead to higher levels of engagement. Taking into consideration that fast-food workers are unique and have their individual needs, potentials, values and goals, it is important that restaurant managers leading through individualised consideration give employees opportunity to grow and progress intellectually. The consequence of this is increased performance for the organisation.

\section{Human resource strategies}

In an endeavour to sustain competition in the market, most organisations craft and implement relevant strategies and look for excellence in what they invest in. Amongst such strategies, Mtshokotshe (2018) refer HR - regarded as critical as some organisations tend to devote less time on HR issues and, hence, lose in the market. Altuntas, Semercioz, Mert and Pehlivan (2014) refer to HR strategies as key components that assist an organisation to reach its competitive goals by recruiting, training and retaining the employees who have essential abilities and motivation consistent with the organisation's strategy. In addition, Rice (2018) found that, HR strategies are not only important in retaining employees who have abilities but current employees are also given opportunities for enhancing the capabilities of operations through expression and creativity. Despite such critical importance of HR strategy, there is a dearth of literature in the South African context on the use of HR strategies in small business, especially in small fast-food restaurants. It is important for restaurant managers to make HR a priority in their organisations in order to address unsatisfactory organisational performance, which can only be addressed by implementing sound HR strategies, amongst others (Mtshokotshe, 2018). In an endeavour to improve organisational performance, general HR strategies rather than specific HR strategies were studied. Armstrong and Taylor (2014) have described HPM, HIM and HCM strategies as an overall system or bundle of complementary HR practices that any organisation can adopt or put into effect in order to improve organisational performance.

\section{High-performance management strategy}

High-performance management strategy refers to a set of HRM practices designed to improve the effectiveness and productivity of employees (Mahdi, Jianqiao, Muhammad, \& Nader, 2014). High-performance management strategy is inclusive of HR practices such as rigorous recruitment and selection procedures, extensive and relevant training and management development activities, incentive pay systems and performance management system. The hospitality industry is saturated with competition and part-time employment practices, coupled with low salaries based on commissions. In relation to competition, HPM strategy is appropriate in this industry as indicated by Yazid et al. (2016) as highly important source of competitive advantage in today's business environment. It is argued that in fast-food restaurants, the recruitment practices are usually ad hoc and training and incentive pay systems are offered (Durrani, 2013; Mtshokotshe, 2018). These HR practices constitute HPM strategy as proposed by Armstrong and Taylor (2014). Therefore, it could be in the best interest for small fast-food restaurants to adopt this strategy. In addition, there is evidence that HPM strategy is not only associated with positive employee-centered outcomes, like higher individual performance, but, amongst others, lower turnover (e.g. Zhang, Akhtar, Bal, Zhang, \& Talat, 2018).

\section{High-involvement management strategy}

High-involvement management strategy refers to policies and procedures that seek to increase employee involvement in management decision-making and to equip employees with the skills and autonomy to identify improvements in organisation processes (Ahmad, 2014). Although there is a good deal of debate as to what set of practices collectively constitute HIM strategy, Wood and Bryson (2009) and Bockerman, Bryson and Ilimakunnas (2013) maintained that core components should include teams, problem-solving groups, informationsharing, incentive and pay, as well as supportive practices, such as training and associated recruitment methods. The hospitality industry has introduced a variety of management practices for spawning high involvement and high performance amongst employees. The range of practices starts from hiring the right people for the organisation. The selected employees are offered, in some instances, basic training, with the hope that the daily practical involvement in the job they get themselves into will provide more skills training and, eventually employee commitment (e.g. AbuKhalifeh, Som, \& AlBattat, 2013). Highinvolvement management strategy promotes, at organisational and team level, information sharing and incentive-based compensation (Ahmad, 2014; Bockerman, Bryson, \& IIimakunnas, 2012). These are the attributes that are encouraged in most restaurant businesses, where, for example servers work in teams, and sometimes their incentives are also team-based. The working in teams is corroborated by Ahmad (2014), who believed that in HIM strategy, workers are more active in teams to achieve the organisational objectives. This corresponds to Dang's (2012) claim that the question of how to gain the highest profits possible (behind the word profits) lays on the hands of the work team.

\section{High-commitment management strategy}

Researchers define HCM strategy as a particular type of high-performance work system that aims to create a psychological bond between the employee and the organisation to ensure that employees are committed to organisational goals (Boon \& Kalshoven, 2014). Rubel, Rimi, Yusliza and Kee (2018) referred to HCM strategy as high-commitment HRM 
(HCHRM) that includes career management, training, information-sharing, appraisals and teamwork. In a case study of symposium restaurant, Dang (2012) discovered that employees offer help to each other so as to be able to complete the teamwork effectively, especially in rush hours. From the teamwork point of view, researchers concur that teamwork is another dimension of HCM strategy requiring information-sharing and collaboration between employees and is critical to building necessary connections that will improve the social capital of a business (Kroll, DeHart-Davis, \& Vogel, 2019; Youndt \& Snell, 2004).

\section{Transformational leadership behaviours and human resource strategies}

Whilst studies suggesting a relationship between TL behaviours and HR strategies exist, literature on this subject is scant. For instance, Hetland, Hetland, Andreassen, Pallesen and Notelaers (2011) and Kovjanic, Schuh, Jonas, Van Quaquebeke and Van dick (2012) showed that transformational leaders, with their behaviours seem to adopt HR strategies such as HIM strategy and that address the three central follower needs: the need for competence (i.e. a sense of mastery and effectiveness), relatedness (i.e. feeling connected and significant to others) and autonomy (i.e. experiencing of volition and choice). In one study, Schopman, Kalshoven and Boon (2015) showed that if transformational leaders care for their workers' feelings and needs, facilitate their skills development, their philosophy of $\mathrm{HR}$ is based on individualised consideration. These studies, however, lack contextual generalisability because they were not conducted in developing countries' context. Some studies (Halle, 2016) have found that a leader can encourage employee involvement by stimulating followers to think and try new ways in completing tasks, asking followers' opinions when making decisions and motivating them to use their capabilities when doing challenging works. This indicates that transformational leaders, through intellectualstimulating behaviour can adopt HR strategies that acknowledge employees' contributions. Similar other studies show that the idealised behaviour of a leader is manifested in collective values and actions taken throughout the organisation, including the type of HR strategies.

A study that investigated high commitment HR strategy found that empowerment enhances commitment (Baumgartner, 2014). Thus, it can be argued that leader who uses inspirational motivation behaviour empowers employees because they emphasise on empowering the employees with the vision. Duong (2015) supported this relationship through a study in the service food industry, which showed that owner-managers empowered their staff to be responsible for the daily running of the restaurant.

Moreover, Wanjiku (2017) postulated that transformational leaders act as catalysts for career management and as such, support the implementation of an integrated framework for career management (hallmark of HCM strategy). This indicates that TL relates to HCM strategy, a reality that is justified by a researcher who found that transformational leaders are more likely to empower employees' career growth by involving them in decision-making and delegating power to them (Men, 2010).

\section{Research design}

The study adopted quantitative approach within the positivist paradigm, through the development of hypotheses and use of statistical analyses, as that allowed the researcher to identify the relationship between TL and HR strategies. The study adopted a descriptive cross-sectional design. This allowed the collection of data across several small fast-food restaurants owner-managers at one time. Demographic information for owner-managers of small fast-food restaurants varied on parameters such as gender, number of years in operation, age, race and position.

\section{Research participants and data collection}

Ninety-two formally registered local small fast-food restaurants owner-managers participated in the study. They were drawn from Mangaung Metropolitan Municipality, Free State province in South Africa. In total, there are 102 owner-managers of small fast-food restaurants within the municipality. Given this small number of small fast-food restaurants, census sampling technique was utilised mainly because census eliminates sampling error and provides data on all the individuals in the population (Baffour, King, \& Valente, 2013). After obtaining ethical clearance and consent from restaurants. A survey questionnaire was distributed over a period of 2 weeks to all the restaurant's owner-managers. The questionnaire was divided into Section A: demographic information, Section B: TL and C: HR strategies. To reach respondents, hand-delivery strategy was followed. This required more travelling time to and from the small fast-food restaurants. Slow response period, meant more reminders through calls and direct visits were needed to ensure timeously completion of the questionnaires. Resultantly, 92 respondents successfully completed the survey questionnaire indicating $90 \%$ response rate.

A Multifactor Leadership Questionnaire (MLQ) adopted from Bass (1985) was used to measure TL. This is a questionnaire that measures TL and is scored on a 5-point Likert scale ranging from 0 (not at all) to 4 (frequently, if not always). It has subscale under TL that is idealised influence, inspirational motivation, intellectual stimulation and individualised consideration. Quintana, Park and Cabrera (2015) used these questionnaire items with hospitality managers and found reliability Cronbach's alpha coefficient ranging between 0.66 and 0.84 for TL subscales. The instruments have been used previously and it has been proved applicable and valid (Shehu \& Mohamad, 2016; Whitelaw, 2013). On the other hand, standard questionnaire was used to determine the extent owner-managers employ HR strategies. Subsequent studies have used questionnaire 
items measuring HPM, HIM and HCM strategy and Cronbach's Alphas were well above the acceptable cut off (e.g. Kooij, Jansen, Dikkers, \& De Lange, 2010; Zhang \& Morris, 2014). Wadhwa (2012) used the same questionnaire items within hospitality and found Cronbach's alphas of 0.83 for high involvement management strategy; hence, the researcher's decision to use them in this study.

\section{Statistical analysis}

Data were cleaned and captured into Microsoft Excel prior to importation into Statistical Package for Social Science (SPSS) version 20. Statistical Package for Social Science provided statistical packages for descriptive statistics to draw a clear picture of the logistics regression analysis. In this study, the Pearson's correlational analysis was used to check the relationship between the perceived TL behaviours and HR strategies.

\section{Ethical considerations}

The Faculty Research and Innovation Committee (FRIC) of the Faculty of Management Sciences, Central University of Technology, Free State, ethically approved the study (approval number FMSEC0018).

\section{Results \\ Descriptive statistics}

The descriptive statistical results for the sample and the response rates are shown in Table 1.

Table 1 shows that $34.8 \%$ of the participants were in the $35-40$ years age group, $26.1 \%$ of the participants in the $30-35$ years age group and $20.7 \%$ of the participants in the 40 years

TABLE 1: Demographical information.

\begin{tabular}{|c|c|c|}
\hline Demographic variables & Frequency & Percentage (\%) \\
\hline \multicolumn{3}{|l|}{ Age (years) } \\
\hline 20 or under & 1 & 1.1 \\
\hline $25-30$ & 16 & 17.4 \\
\hline $30-35$ & 24 & 26.1 \\
\hline $35-40$ & 32 & 34.8 \\
\hline 40 or over & 19 & 20.7 \\
\hline \multicolumn{3}{|l|}{ Race } \\
\hline Black people & 44 & 47.8 \\
\hline White people & 21 & 22.8 \\
\hline Indian & 4 & 4.3 \\
\hline Mixed race & 13 & 14.1 \\
\hline Others & 10 & 10.9 \\
\hline \multicolumn{3}{|l|}{ Gender } \\
\hline Female & 48 & 52.2 \\
\hline Male & 44 & 47.8 \\
\hline Position & & 21.7 \\
\hline Other & 20 & \\
\hline Manager & 72 & 78.3 \\
\hline \multicolumn{3}{|l|}{ Number of years } \\
\hline Less than one & 12 & 13.0 \\
\hline $1-2$ & 30 & 32.6 \\
\hline $3-4$ & 23 & 25.0 \\
\hline $5-6$ & 17 & 18.5 \\
\hline 7 or more & 10 & 10.9 \\
\hline
\end{tabular}

and above age group, $17.4 \%$ of the participants in the 25-30 years age group and only $1.1 \%$ of the participants in the 20 years or underage group. In terms of race, most of the participants $(47.8 \%)$ were black people, $22.8 \%$ were white people, $14.1 \%$ being mixed race with only $4.3 \%$ being Indian and $10.9 \%$ other races. There were slightly more female participants $(52.2 \%)$ than male $(47.8 \%)$. Most of the participants $(78.3 \%)$ were managers whilst $21.7 \%$ of the participants were owners. As shown in Table 1, 32.6\% of the participants had been in the business for 1-2 years, $25.0 \%$ for $3-4$ years, $18.5 \%$ for $5-6$ years, $13 \%$ for less than 1 year and $10.9 \%$ for 7 years or more.

\section{Hypothesis testing}

To evaluate if TL behaviours are correlated with HR strategies, five correlation analyses were used to test the following hypothesis:

H1: Owner-managers' inspirational motivation behaviour do correlate with HCM strategy relevant to small fast-food restaurants.

H2: Owner-managers' individualised consideration behaviour do correlate with HPM strategy relevant to small fast-food restaurants.

H3: Owner-managers' idealised influence behaviour do correlate with HPM strategy relevant to small fast-food restaurants.

H4: Owner-managers' intellectual stimulation behaviour do correlate with HIM strategy relevant to small fast-food restaurants.

H5: Owner-managers' individualised consideration behaviour do correlate with HIM strategy relevant to small fast-food restaurants.

Table 2 shows that the dimensions of HCM strategy that were significantly correlated with inspirational motivation behaviour were information-sharing (correlation $=0.293, p=0.005$ ), appraisals (correlation $=0.281 p=0.007$ ) and Training (correlation $=0.262, p=0.012$ ). The dimensions of career management (correlation $=0.179, p=0.087$ ) and teamwork (correlation $=0.172, p=0.101$ ) were not significantly correlated with HCM strategy. In this regard, inspirational motivation behaviour is significantly correlated with HCM strategy. However, the effect size was small (significant correlations ranging from 0.262 to 0.293 ) because not all facets of HCM strategy were significantly correlated with inspirational motivation behaviour.

The results in Table 3 show that the HPM strategy dimension of training and development is significantly correlated with TL behaviour dimension of individualised consideration (correlation $=0.259, p=0.013$ ). The HPM strategy dimensions of recruitment and selection (correlation $=0.228, p=0.029$ ) and participation (correlation $=0.282, p=0.006$ ) were also significantly correlated with TL behaviour dimension of individualised consideration. The other two HPM strategy dimensions of performance appraisals (correlation $=0.097$, $p=0.359$ ) and rewards (correlation $=0.171, p=0.104$ ) were not significantly correlated with the TL behaviour 
TABLE 2: Correlations of transformational leadership behaviour - Inspirational motivation and high-commitment management strategy.

\begin{tabular}{lc}
\hline Pearson's correlations & $\begin{array}{c}\text { Transformational leadership behaviour - } \\
\text { Inspirational motivation }\end{array}$ \\
\hline High-commitment management strategy & $0.293^{* *}$ \\
Information-sharing & 0.005 \\
Correlation & 92 \\
$p$ & \\
$N$ & 0.179 \\
Career management & 0.087 \\
Correlation & 92 \\
$p$ & \\
$N$ & $0.281^{* *}$ \\
Appraisals & 0.007 \\
Correlation & 92 \\
$p$ & \\
$N$ & $0.262^{*}$ \\
Training & 0.012 \\
Correlation & 92 \\
$p$ & \\
$N$ & 0.172 \\
Teamwork & 0.101 \\
Correlation & 92 \\
$p$ & \\
$N$ & \\
& \\
\hline Corrention & \\
$p$ & \\
\hline & \\
&
\end{tabular}

*, Correlation is significant at the 0.05 level (2-tailed).

**, Correlation is significant at the 0.01 level (2-tailed).

dimension of individualised consideration. Therefore, these results indicate that individualised consideration behaviour significantly correlate with HPM strategy although the effect size is small (significant correlations ranging from 0.228 to 0.282 ) because only three out of five facets of HPM strategy are significantly correlated with individualised behaviour.

The correlation results presented in Table 4 show that none of the five dimensions of HPM strategy are significantly correlated with idealised influence behaviour.

The results in Table 5 show that the HIM strategy dimension of recruitment is significantly correlated with TL behaviour dimension of intellectual stimulation behaviour (correlation $=$ $0.285, p=0.006$ ). The results also show that the HIM strategy dimensions of training (correlation $=0.252$, $p=0.015$ ), participation (correlation $=0.330, p=0.001$ ) and rewards (correlation $=0.356, p=0.001$ ), are also significantly correlated with TL behaviour dimension of intellectual stimulation behaviour. Briefly, four out of four HIM strategy dimensions are significantly correlated with TL behaviour dimension of intellectual stimulation. Thus, HIM strategy is significantly correlated with TL behaviour dimension of intellectual stimulation, even though effect is slightly small ranging from correlation $=0.252$ to correlation $=0.356$.

The results in Table 6 show that the HIM strategy dimensions of recruitment (correlation $=0.280, p=0.007$ ) and participation (correlation $=0.223, p=0.033$ ), are significantly correlated with the TL behaviour dimension of individualised
TABLE 3: Correlations of transformational leadership behaviour - Individualised consideration and high-performance management strategy.

\begin{tabular}{|c|c|}
\hline Pearson's correlations & $\begin{array}{c}\text { TL behaviour - Individualised } \\
\text { consideration }\end{array}$ \\
\hline \multicolumn{2}{|c|}{ High-performance management strategy } \\
\hline \multicolumn{2}{|c|}{ Training and development } \\
\hline Correlation & $0.259 *$ \\
\hline$p$ & 0.013 \\
\hline$N$ & 92 \\
\hline \multicolumn{2}{|c|}{ Recruitment and selection } \\
\hline Correlation & $0.228^{*}$ \\
\hline$p$ & 0.029 \\
\hline$N$ & 92 \\
\hline \multicolumn{2}{|l|}{ Performance appraisal } \\
\hline Correlation & 0.097 \\
\hline$p$ & 0.359 \\
\hline$N$ & 92 \\
\hline \multicolumn{2}{|l|}{ Rewards } \\
\hline Correlation & 0.171 \\
\hline$p$ & 0.104 \\
\hline$N$ & 92 \\
\hline \multicolumn{2}{|l|}{ Participation } \\
\hline Correlation & $0.282^{* *}$ \\
\hline$p$ & 0.006 \\
\hline$N$ & 92 \\
\hline
\end{tabular}

TABLE 4: Correlations of transformational leadership behaviour - Idealised influence and high-performance management strategy.

\begin{tabular}{|c|c|}
\hline Pearson's correlations & TL behaviour - Idealised influence \\
\hline \multicolumn{2}{|c|}{ High-performance management strategy } \\
\hline \multicolumn{2}{|c|}{ Training and development } \\
\hline Correlation & 0.029 \\
\hline$p$ & 0.788 \\
\hline$N$ & 90 \\
\hline \multicolumn{2}{|c|}{ Recruitment and selection } \\
\hline Correlation & 0.101 \\
\hline$p$ & 0.343 \\
\hline$N$ & 90 \\
\hline \multicolumn{2}{|l|}{ Performance appraisal } \\
\hline Correlation & 0.083 \\
\hline$p$ & 0.436 \\
\hline$N$ & 90 \\
\hline \multicolumn{2}{|l|}{ Rewards } \\
\hline Correlation & 0.106 \\
\hline$p$ & 0.320 \\
\hline$N$ & 90 \\
\hline \multicolumn{2}{|l|}{ Participation } \\
\hline Correlation & 0.199 \\
\hline$p$ & 0.060 \\
\hline$N$ & 90 \\
\hline
\end{tabular}

consideration whilst training (correlation $=0.066, p=0.532$ ) and rewards (correlation $=0.125, p=0.234$ ) significantly do not correlate with TL behaviour dimension of individualised consideration. In short, out of four dimensions of HIM strategy, only recruitment and participation significantly correlate with TL behaviour dimension of individualised consideration with small effect size ranging from correlation = 0.223 to correlation $=0.280$. 
TABLE 5: Correlations of transformational leadership behaviour - Intellectual stimulation and high-involvement management strategy.

\begin{tabular}{lc}
\hline Pearson's correlations & TL behaviour - Intellectual stimulation \\
\hline High-involvement management strategy & \\
Recruitment & $0.285^{* *}$ \\
Correlation & 0.006 \\
$p$ & 92 \\
$N$ & \\
Training & $0.252^{*}$ \\
Correlation & 0.015 \\
$p$ & 92 \\
$N$ & \\
Participation & $0.330^{* *}$ \\
Correlation & 0.001 \\
$p$ & 92 \\
$N$ & \\
Rewards & $0.356^{* *}$ \\
Correlation & 0.001 \\
$p$ & 92 \\
$N$ & \\
\hline TL, transformational leadership. & \\
$*$, Correlation is significant at the 0.05 level (2-tailed). & \\
$* *$ Correlation is significant at the 0.01 level (2-tailed). &
\end{tabular}

TABLE 6: Correlations of transformational leadership behaviour - Individualised consideration and high-involvement management strategy.

\begin{tabular}{lc}
\hline Pearson's correlations & $\begin{array}{c}\text { TL behaviour }- \text { Individualised } \\
\text { consideration }\end{array}$ \\
\hline High-involvement management strategy & $0.280^{* *}$ \\
Recruitment & 0.007 \\
Correlation & 92 \\
$p$ & \\
$N$ & 0.066 \\
Training & 0.532 \\
Correlation & 92 \\
$p$ & \\
$N$ & $0.223 *$ \\
Participation & 0.033 \\
Correlation & 92 \\
$p$ & \\
$N$ & 0.125 \\
Rewards & 0.234 \\
Correlation & 92 \\
$p$ &
\end{tabular}

$\mathrm{TL}$, transformational leadership.

*, Correlation is significant at the 0.05 level (2-tailed).

**, Correlation is significant at the 0.01 level (2-tailed).

\section{Discussion}

The objective of the study was to determine the extent to which owner-managers' TL behaviours and HR strategies correlate. Table 2 shows that from the three out of five HCM strategy constructs, only information-sharing, appraisals and training were significantly correlated with TL Inspirational motivation dimension. This means that HCM strategy is significantly correlated with TL behaviour dimension of inspirational motivation even though the effect sizewas small. Despite this, and, considering that inspirational motivation symbolises the charismatic aspect of TL (Bass \& Avolio, 1994), these results are consistent with the results of Horn, Mathis, Robinson and Randle (2013). These researchers found that there is a positive relationship between perceived leader charisma and commitment (consequence of HCM strategy). This also extends Vermeeren (2014)'s findings that TL is associated with commitmentoriented HRM.

The results in Table 3 indicate that from the three out of five HPM strategy dimensions, only training and development, recruitment and selection and participation were significantly correlated with TL behaviour dimension of individualised consideration. This means that HPM strategy significantly correlate with TL behaviour-individualised consideration, even though the effect size was also small. These results confirm earlier research by Vekeman, Devos and Valcke (2016) that TL can be linked to a high HR orientation as transformational leaders are characterised by individualised consideration of the needs of their employees. This means owner-managers who display individualised consideration are able to configure HR practices according to the specific needs of their employees.

The results in Table 4 revealed that none of HPM strategy dimensions correlate with TL behaviour-idealised influence. Considering that, idealised influence behaviour may be referred to as behaviourally based charismatic leadership (Harms \& Crede, 2010), these results are in concurrence with Jacquart and Antonakis (2015)'s declaration that when performance signals are clear, the charisma of leader does not matter. This might have been the case in this study, hence, none of the high-performance HR practices significantly correlated with TL behaviour-idealised influence behaviour. The results are, however, nullified by De Vries, Pathak and Paquin (2011) who found that charismatic leadership is generally related to positive team outcomes and performance (HPM strategy outcome). In support, Wilderom, Van Den berg and Wiersma (2012) further found a positive relationship between perceived leader charisma and performance (HPM strategy outcome).

The significant correlation between TL behaviour-intellectual stimulation and HIM strategy is supported by the results of a previous study by Shin, Jeong and Bae (2018). These researchers found that a bundle of high-involvement HR practices (HIHRPs) was positively related to individual worker creativity (hallmark of intellectual stimulation). Considering that a leader's intellectual stimulation can motivate individual creative behaviours (Cekmecelioglu \& Ozbag, 2016), this means that HIHRPs is an antecedent to intellectual stimulation behaviour. Therefore, ownermanagers can implement HIM strategy not only to promote high-involvement culture but also to sharpen intellectual stimulation behaviour within their employees.

Lastly, the results indicated that out of four dimensions of HIM strategy, only recruitment and participation seem to be significantly correlated with TL behaviour dimension of individualised consideration. Whilst the other two HIM strategy-dimensions (training and rewards) measured did not significantly correlate with TL behaviour-individualised consideration, from participation (dimension of HIM 
strategy) point of view, one can argue that individualised consideration is central to participative leadership, which focuses on followers' personal growth and needs and is concerned with decisions affecting their work (Hautamaki, 2016). This means that participative leadership and individualised consideration are two sides of the same coin. In this case, according to Miao, Newman, Schwarz and $\mathrm{Xu}$ (2013), participative leaders facilitate subordinate involvement (sign of HIM strategy) in the decision-making process through encouragement, resource provision, support and influence. This implies that HIM strategy and TL behaviour-individualised consideration do correlate, although not all paths are statistically significant.

\section{Practical implications}

Considering the importance of TL behaviours, specifically inspirational motivation, individualised consideration and intellectual stimulation, this style of leadership should not be disregarded completely when considering HRM issues in SMMEs, especially small fast-food restaurants. In this regard, HR agents involved in SMME HR development work could benefit from this study by designing workshops to train owner-managers on the importance of TL and HR strategies.

\section{Limitation and recommendations for future studies}

The results obtained are based on small fast-food restaurants in one area. Therefore, the results might not hold true for other fast-food restaurants in other areas, indicating the lack of substance for generalisation. For this study, the sample was chosen on the basis of convenience sampling, therefore, the research study was deprived of its probability of representativeness. It is recommended that future researchers extend the results by requesting restaurant employees to answer questionnaires to rate their owner-managers. The results can, therefore, indicate whether owner-managers have given out honest responses regarding their TL behaviours. Lastly, expanding the study could be extended to other business within the hospitality sector and the results can be compared.

\section{Conclusion}

The study contributes to the debate on HRs management amongst small businesses, an area often neglected because of its smallness. The study, therefore, demonstrated how the precepts of transformational leadership behaviours and HR strategies can be critical to be developed amongst ownermanagers of small businesses in the hospitality sector.

\section{Acknowledgements}

The authors acknowledge Central University of Technology, Free State and the National Research Foundation for providing the grant for the study, as well as all small-restaurant businesses that voluntarily participated in the study.

\section{Competing interests}

The authors have declared that no competing interest exists.

\section{Authors' contributions}

Both authors contributed equally to this work.

\section{Funding information}

Funding for this research was provided for by the Central University of Technology Free State and the National Research Foundation (NRF South Africa).

\section{Data availability}

The data that support the findings of this study are available from the corresponding author (C.C.) upon reasonable request.

\section{Disclaimer}

The views and opinions expressed in this article are those of the authors and do not necessarily reflect the official policy or position of any affiliated agency of the authors.

\section{References}

AbuKhalifeh, A.N., Som, A.P., \& AlBattat, A.R. (2013). Human resource management practices on food and beverage performance a conceptual framework for the Jordan hotel industry. Journal of Tourism and Hospitality, 2(1), 1-3. https://doi. org/10.4172/2167-0269.1000111

Ahmad, M. (2014). High involvement management and employees performance mediating role of job satisfaction. European Journal of Business and Management, 6(31), 230-243.

Alahmad, Y.Y. (2016). Understanding the relationship between idealized influence, intellectual stimulation, inspirational motivation, individualized consideration and product innovation among manufacturing and services firms: The role of open system. Doctoral dissertation, (pp. 1-173). Ohio: University of Toledo.

Altuntas, G., Semercioz, F., Mert, A., \& Pehlivan, C. (2014). Industry forces and functional strategies and organisational performance: Evidence from restaurants in Istanbul, Turkey. Procedia - Social and Behavioural Sciences, 150(1), 300-309. https://doi.org/10.1016/j.sbspro.2014.09.066

Armstrong, M. \& Taylor, S. (2014). Armstrong's handbook of human resource management practice. London: Kogan page.

Atiku, S.O., \& Anane-Simon, R. (2020). Leadership and innovative approaches in higher education. In N. Baporikar, \& M. Sony (Eds.), Quality management principles and policies in higher education, (pp. 83-100). Hershey, PA: IGI Global.

Baffour, B., King, T., \& Valente, P. (2013). The modern census: Evolution, examples and evaluation. International Statistical Review, 81(3), 407-425. https://doi.org/ 10.1111/insr.12036

Bass, B. (1985). Leadership and performance beyond expectations. New York: Free Press.

Bass, B.M., \& Avolio, B.J. (1994). Improving organisational effectiveness through transformational leadership. London: Sage Publications India Pvt. Ltd.

Bass, B.M., \& Riggio, R. E. (2006). Transformational Leadership. Mahwah, NJ: Lawrence Erlbaum Associates.

Baumgartner, J. (2014). Benefits of employee empowerment for service quality and job satisfaction in the hospitality industry. Bachelor thesis, (pp. 1-87). Austria: Modu Vienna University.

Bockerman, P., Bryson, A., \& limakunnas, P. (2012). Does high involvement management improve worker wellbeing? Journal of Economic Behaviour and Organisations, 84(2), 660-680. https://doi.org/10.1016/j.jebo.2012.09.005

Bockerman, P., Bryson, A., \& Ilmakunnas, P. (2013). Does high involvement management lead to higher pay? Journal of the Royal Statistical Society, 176(4), 861-885. https://doi.org/10.1111/j.1467-985X.2012.01075.x

Boon, C., \& Kalshoven, K. (2014). How high-commitment HRM relates to engagement and commitment: The moderating role of task proficiency. Human Resource Management, 53(3), 403-420. https://doi.org/10.1002/hrm.21569

Cekmecelioglu, H.G., \& Ozbag, K.G. (2016). Leadership and creativity. The impact of transformational leadership on individual creativity. Procedia-Social and Behavioural Sciences, 235, 243-249. https://doi.org/10.1016/j.sbspro.2016.11.020.

Chou, S.F., Horng, J.S., Liu, C.H., Huang, Y.C., \& Chung, Y.C. (2016). Expert concepts of sustainable service innovation in restaurants in Taiwan. Sustainability, 8(8), 739-758. https://doi.org/10.3390/su8080739 
Dang, H.T. (2012). Communication gaps at seasonal restaurants case study: Symposium Restaurant Crete Island, Greece. Masters dissertation. Crete Island, Greece: University of Applied Sciences.

De Vries, R.E., Pathak, R.D., \& Paquin, A.R. (2011). The paradox of power sharing Participative charismatic leaders have subordinates with more instead of less need for leadership. European Journal of Work and Organisational Psychology, 20(6), 779-804. https://doi.org/10.1080/1359432X.2010.509923

Durrani, A.S. (2013). Current hiring practices in the restaurant industry: An example of California restaurants. Doctoral dissertation, (pp. 1-130). California: lowa State University.

Duong, H.A. (2015). The effect of employee empowerment on service quality in foodservice firms. Bachelor thesis. Jyvaskyla: JAMK University of Applied Sciences.

Elgelal, K.S.K., \& Noermijati, N. (2014). The influences of transformational leadership on employees performance. Asia Pacific Management and Business Application,
3(1), 48-66. https://doi.org/10.21776/ub.apmba.2014.003.01.4

Gonfa, B.D. (2019). Review on components of transformational leadership. Arabian Journal of Business and Management Review, 9(3), 1-5.

Gumusluoğlu, L., \& Ilsev, A. (2009). Transformational leadership and organizational innovation: The roles of internal and external support for innovation. Journal of Product Innovation Management, 26(3), 264-277. https://doi.org/10.1111 /j.1540-5885.2009.00657.x

Halle, A.Y. (2016). Influence of leader and follower behaviour on employee voice, team task responsibility, and team effectiveness. Master thesis. Enschede: University of Twente.

Hamidianpour, F., Esmaeilpour, M., \& Mashayekh, S. (2016). Studying the effect of transformational leadership style on organizational culture change. Journal of
Academy of Business and Economics, 16(2), 7-24. https://doi.org/10.18374/JABE$16-2.1$

Harms, P.D., \& Crede, M. (2010). Emotional intelligence and transformational and transactional leadership: A meta-analysis. Journal of Leadership and
Organisational Studies, 17(5), 1-17. https://doi.org/10.1177/1548051809350894

Hautamaki, P. (2016). Leading with individual consideration - Forming value with customers in business interactions. Doctoral dissertation. University of Vaasa.

Hetland, H., Hetland, C., Andreassen, C.S., Pallesen, S., \& Notelaers, G. (2011). Leadership and fulfilment of the three basic psychological needs at work. The Career Development International, 16(5), 507-523. https://doi.org/10.1108/13620431111168903

Horn, D., Mathis, C.J., Robinson, S.L., \& Randle, N. (2013). Is charismatic leadership effective when workers are pressured to be good citizens? Journal of Psychology, 149(8), 751-774. https://doi.org/10.1080/00223980.2014.978253

Insight Survey. (2016). Is SA's love for fast food still growing? Retrieved from https:// www.bizcommunity.com/Article/196/19/151362.html

Jacquart, P., \& Antonakis, J. (2015). When does charisma matter for top-level leaders? Effect of attribution ambiguity. Academy of Management Journal, 58(4),

Kooij, D.T., Jansen, P.G., Dikkers, J.S., \& De Lange, A.H. (2010). The influence of age on the associations between $\mathrm{HR}$ practices and both affective commitment and job satisfaction: A meta-analysis. Journal of Organisational Behaviour, 31(8), 1111-1136. https://doi.org/10.1002/job.666

Korejan, M.M., \& Shahbazi, H. (2016). An analysis of the transformational leadership theory. Journal of Fundamental and Applied Sciences, 8(3S), 452-461. https://doi. org/10.4314/jfas.v8i3s.192

Kovjanic, S., Schuh, S.C., Jonas, K., Van Quaquebeke, N., \& Van Dick, R. (2012), How do transformational leaders foster positive employee outcomes? A self-determination based analysis of employees needs as mediating links. Journal of Organisational Behaviour, 33(8), 1031-1052. https://doi.org/10.1002/job.1771

Kroll, A., DeHart-Davis, L., \& Vogel, D. (2019). Mechanisms of social capital in organizations: How team cognition influences employee commitment and engagement. The American Review of Public Administration, 49(7), 777-791. https://doi.org/10.1177/0275074019851894

Mahdi, S.M., Jianqiao, L., Muhammad, S., \& Nader, H.M. (2014). The impact of high performance work system (HPWS) on employee productivity as related to organizational identity and job engagement. European Journal of Business and

McKinnon-Russell, T. (2015). Transformational leadership principles within small businesses. Doctoral dissertation, Minneapolis: Walden University.

Mhlanga, O. (2018). The fast food industry in South Africa: The microenvironment and its influence. African Journal of Hospitality, Tourism and Leisure, 7(4), 1-16.

Miao, Q., Newman, A., Schwarz, G., \& Xu, L. (2013). Participative leadership and the organisational commitment of civil servants in China: The mediating effects of
trust in supervisor. British Journal of Management, 24(1), 76-92. https://doi. trust in supervisor. British Journa
org/10.1111/1467-8551.12025

Mtshokotshe, Z. (2018). The implementation of human resources management strategy within restaurants in East London, South Africa. African Journal of Hospitality, Tourism and Leisure, 7(3), 1-15.

Mupani, H., \& Chipunza, C. (2019). Environmental influences, employee resourcing strategies and small and medium-sized enterprises performance: Case of South African small restaurants. SA Journal of Human Resource Management, 17
a1104. https://doi.org/10.4102/sajhrm.v17i0.1104

Ngaithe, L., George, K.G., Lewa, P., \& Ndwiga, M. (2016). Effect of idealized influence and inspirational motivation on staff performance in state owned enterprises in Kenya. European Journal of Business and Management, 8(30), 6-13.

Nyandiko, J.A., \& Ongeri, L. (2015). Effectiveness of strategic human resource management on organisational performance at Kenya Seed Company. Journal of Emerging Trends in Economics and Management Sciences, 6(1), 1-5.

Nzonzo, J.C., \& Matashu, M. (2014). An insight into the human resource management practices adopted by entrepreneurs in South Africa. Journal of Small Business and Entrepreneurship Development, 2(3-4), 73-87. https://doi.org/10.15640/jsbed. v2n3-4a5
Odumeru, J.A., \& Ifeanyi, G.O. (2013). Transformational vs. transactional leadership theories: Evidence in literature. International Review of Management and Business Research, 2(2), 355-361.

Ogola, M.G.O., Sikalieh, D., \& Linge, T.K. (2017). The influence of individualised consideration leadership behaviour on employee performance in small and medium enterprises in Kenya. International Journal of Business and Social Science, 8(2), 163-173.Quintana, T.A., Park, S., \& Cabrena, Y.A. (2015). Assessing the effects of leadership styles on employees' outcomes in international luxury effects of leadership styles on employees' outcomes in international luxury
hotels. Journal of Business Ethics, 129(2), 469-489. https://doi.org/10.1007/ s10551-014-2170-3

Rice, D. (2018). Human resources: Strategic, predictive and cost effective Retrieved from https://https://www hrexchangenetwork.com/hr-talentmanagement/articles/human-resources-strategic-predictive-and-cost-effective

Rubel, M.R.B., Rimi, N.N., Yusliza, M.Y., \& Kee, D.M.H. (2018). High commitment human resource management practices and employee service behaviour: Trust in management as mediator. IIMB Management Review, 30(4), 316-329. https:// doi.org/10.1016/j.iimb.2018.05.006

Schopman, L.M., Kalshoven, K., \& Boon, C. (2015). When health care workers perceive high-commitment HRM will they be motivated to continue working in health care? It may depend on their supervisor and intrinsic motivation. The Internationa Journal of Human Resource Management, 28(5), 657-677. https://doi.org/10.108 $0 / 09585192.2015 .1109534$

Shehu, A., \& Mohamad, W. (2016). Leadership style and the adoption of electronic commerce among Malaysian fast-food restaurant managers. International Journa of Accounting and Business Management, 4(2), 302-313.

Shin, S.J., Jeong, I., \& Bae, J. (2018). Do high-involvement HRM practices matter for worker creativity? A cross-level approach. International Journal of Human Resource Management, 29(2), 260-285. https://doi.org/10.1080/09585192.20 15.1137612

Smith, J.D. 2018. Successful strategies for reducing employee turnover in the restaurant industry. Doctoral dissertation. Minneapolis: Walden University.

South Africa Hotel \& Restaurant Institutional Sector Report. (2016). Assessments of commodity and trade issues made by USDA staff and not necessarily statements of official U.S. Government Policy. Pretoria: Global Agricultural Information Network.

Steinmann, B., Klug, H.J.P., \& Maier, G.W. (2018). The path is the goal: How transformational leaders enhance followers' job attitudes and proactive behaviour. Frontiers in Psychology, 9, a2338. https://doi.org/10.3389/fpsyg.2018.02338

Ukandu, N.E., \& Ukpere, W.I. (2011). Strategies to improve the level of employee motivation in the fast food outlets in Cape Town, South Africa. African Journa of Business Management, 5(28), 11521-11531. https://doi.org/10.5897/ AJBM11.1476

Vekeman, E., Devos, G., \& Valcke, M. (2016). Linking educational leadership styles to the HR architecture for new teachers in primary education. SpringerPlus, 5(1), 1-19. https://doi.org/10.1186/s40064-016-3378-8

Vermeeren, B. (2014). Variability in HRM implementation among line managers and its effect on performance: A 2-1-2 mediational multilevel approach. International Journal of Human Resources Management, 25(22), 3039-3059. https://doi.org/1 $0.1080 / 09585192.2014 .934891$

Wadhwa, P. (2012). The relationship between high involvement work systems, supervisory support, and organisational effectiveness: The role of employee experiences at work. Doctoral dissertation. University of Kansas.

Wanjiku, N.S. (2017). Factors affecting implementation of career management programs in the public sector in Kenya: A case study of Kenya tourism fund. Bachelor dissertation. Nairobi: Management University of Africa.

Whitelaw, P.A. (2013). Leadership up the ladder: The construction of leadership style in the hospitality industry. Journal of Contemporary Issues in Business and Government, 19(1), 65-79. https://doi.org/10.7790/cibg.v19i1.9

Wilderom, C.P., Van Den Berg, P.T., \& Wiersma, U.J. (2012). A longitudinal study of the effects of charismatic leadership and organisational culture on objective and perceived corporate performance. The Leadership Quarterly, 23(5), 835-848. https://doi.org/10.1016/j.leaqua.2012.04.002

Wood, S., \& Bryson, A. (2009). High involvement management. In W. Brown, A. Bryson, J. Forth, \& K. Whitfield (Eds.), The evolution of the modern workplace, (pp. 151-175). Cambridge and New York: Cambridge University Press.

Yazid, Z.N.A., Yahya, W.K., Ishak, M., \& Achim, N. (2016). High Performance Work System (HPWS) and Organizational Performance: The Mediating Role of Employee Attitude. World journal of Management and Behavioural Studies, 20(10), 1-8. https://www.researchgate.net/project/

Youndt, M., \& Snell, S. (2004). Human resource configurations, intellectual capital, and organizational performance. Journal of Managerial Issues, 16(3), 337-360. https://doi.org/10.1037/t68746-000

Zhang, J., Akhtar, M.N., Bal, P.M., Zhang, Y., \& Talat, U. (2018). How do highperformance work systems affect individual outcomes: A multilevel perspective. Journal of Frontiers in Psychology, 9(586), 1-13. https://doi.org/10.3389/ fpsyg.2018.00586

Zhang, B., \& Morris, J.L. (2014). High-performance work systems and organisational performance: Testing the mediation role of employee outcomes using evidence from PR China. The International Journal of Human Resource Management, 25(1) 68-90. https://doi.org/10.1080/09585192.2013.781524

Zwane, F.N., Du Plessis, L., \& Slabbert, E. (2014). Analysing the skills expectations of employers in the South African tourism industry. SA Journal of Human Resource Management, 12, 550-559. https://doi.org/10.4102/sajhrm.v12i1.550 